\title{
Brillantasia patula Aqueous Leaf Extract Averts Hyperglycermia, Lipid Peroxidation, and Alterations in Hematological Parameters in Alloxan-Induced Diabetic Rats
}

\author{
Akpovwehwee Akporhuarho Anigboro, ", Oghenetega Jonathan Avwioroko², \\ Nyerhovwo John Tonukari ${ }^{1}$ \\ ${ }^{1}$ Department of Biochemistry, Faculty of Science, Delta State University, Abraka, Nigeria \\ ${ }^{2}$ Biochemistry Division, Department of Chemical Sciences, College of Natural Sciences, Redeemer's University, Ede, Nigeria
}

\section{Email address:}

akposanigboro@gmail.com(A. A. Anigboro), akposanigboro@yahoo.co.uk(A. A. Anigboro),joavwioroko@gmail.com(O. J. Avwioroko), tonukari@gmail.com(N. J. Tonukari)

${ }^{*}$ Corresponding author

\section{To cite this article:}

Akpovwehwee Akporhuarho Anigboro, Oghenetega Jonathan Avwioroko, Nyerhovwo John Tonukari. Brillantasia patula Aqueous Leaf Extract Averts Hyperglycermia, Lipid Peroxidation, and Alterations in Hematological Parameters in Alloxan-Induced Diabetic Rats. International Journal of Biomedical Science and Engineering. Vol. 6, No. 2, 2018, pp. 43-51. doi: 10.11648/j.ijbse.20180602.14

Received: May 27, 2018; Accepted: June 26, 2018; Published: July 24, 2018

\begin{abstract}
The protective effects of aqueous leaf extract of Brillantasia patula against hyperglycermia, lipid peroxidation, and alterations in hematological parameters in diabetic Wistar rats were investigated. The study consisted of six treatment groups, with five animals each, designated as Group-1 (healthy), Group-2 (diabetic control) and Groups 3-6 (diabetic rats treated with 500, 1000, 1500, and $2000 \mathrm{mg} / \mathrm{kgbwt}$ of extract, respectively). Rats were administered their respective doses orally, and daily, for 14 days. Thereafter, the effects on serum glucose levels, liver and kidney functions, lipid peroxidation, free radical scavenger and hematological parameters were analyzed. Blood glucose levels reduced markedly in diabetic rats given the plant extract relative to diabetic control. Both serum creatinine and urea decreased significantly in treated diabetic rats at extract doses of $1000 \mathrm{mg} / \mathrm{kgbwt}$ and above. Reductions in serum cholesterol $(\mathrm{p}<0.05)$ and triglyceride levels $(\mathrm{p}<0.05)$ were also observed. Elevated total serum protein and globulin in diabetic control was decreased in all treated groups. Haematological indices of groups given the extract were noticeably enhanced. Similarly, kidney, heart and liver glutathione (GSH) levels increased significantly in groups treated compared to diabetic control; lipid peroxidation in kidney and heart also decreased significantly in all the treated groups. Liver catalase activity improved. Serum alanine and aspartate aminotransferases activities widely lowered in Groups 3 and 4. The study indicates that Brillantaisia patula aqueous leaf extract exhibits potential hypoglycemic effect, prevents lipid peroxidation, boosts haematological parameters, and could protect liver and renal damage associated with diabetes especially at doses of $500-1000 \mathrm{mg} / \mathrm{kgbwt}$.
\end{abstract}

Keywords: Diabetes Mellitus, Brillantasia patula, Hypoglycemic Effect, Lipid Peroxidation, Antioxidants, Haematological Indices

\section{Introduction}

Diabetes mellitus is a group of heterogeneous, autoimmune, hormonal, metabolic, hyperlipidaemia and obesity disease [1]. It is typified by inappropriate high blood glucose level caused by complete or relative deficiency of insulin or resistance to the action of insulin caused by receptor cells. It can be categorized into two: Type 1(insulin deficiency) and Type 2 (insulin receptor cells not active) [2]. It is also characterized by elevated total or low density lipoprotein (LDL) cholesterol in the blood, polyuria, albuminuria, renal enlargement and a rise in serum creatinine [3].

Different plants extracts have been used in the management of many different illnesses $[4,5]$ and many of these plant species have been demonstrated to have hypoglycemic effect [6]. Many indigenous plants, shrubs, herbs, twigs and leafy vegetables are taken as food, spices or 
used in medicinal purposes in Nigeria [7]. Evaluation of the efficacy of plants in areas where there is no availability of safe modern drugs has also been advocated [8].

The use of plants in the management of diseases lies on their chemical compositions which give unique physiological roles in the human body [9]. The active components of most plants are tannin, flavonoid, alkaloids, phenol compounds, saponin, glycoside, anthraquinones etc [10]. Phytochemicals isolated from plant sources are used for the prevention and treatment of cancer, heart disease, diabetes mellitus and high blood pressure [11]. Brillantasia patula is a medicinal plant used for animals in Africa. B. patula belongs to the family Acanthaceae; it is a shrubby plant of about $3 \mathrm{~m}$ height and can be found in Nigeria, Togo, West Cameroun and across Uganda and Angola. Yaws and rheumatism have also been treated with the leaves of this herb. The decoction is taken to ease childbirth, menstrual pain and stomach ache. It is reported to have anti-plasmodial and analgesic potentials [12].

In this study, we investigated the protective effects of aqueous leaf extract of Brillantasia patula against hyperglycermia, lipid peroxidation, and alterations in haematological parameters in alloxan-induced diabetic Wistar rats.

\section{Materials and Methods}

\subsection{Experimental Animals}

Female wistar rats that weighed $88-206 \mathrm{~g}$ and thirty in number were used in this study. They were bred in the animal house of African Research Laboratory, Isiokolo, Delta State. They were kept in constructed cages with wire gauze under control condition of 12 light/12 dark cycle. The animals were fed ad libitum on water and growers marsh obtained from Top feeds, Sapele, Delta State. All the experimental animals were taken care of in line with the principles of the National Institutes of Health (NIH Publications No. 8023, revised 1978).

\subsection{Chemicals}

Alloxan monohydrate used for this study was obtained from Alpha Chimika, Mumbia, China. All other reagents used were of standard quality also.

\subsection{Induction of Diabetes in Experimental Rats}

Rats were fed normal feed and water for one week after which they were fasted for $12 \mathrm{hr}$ before intraperitoneal injection of a dose of $120 \mathrm{mg} / \mathrm{kg}$ body weight of alloxan monohydrate [1]. Blood collected from tail reins was used to confirm diabetes induction using a glucometer (EasyGluco ${ }$, US Diagnostics). The level of random blood glucose considered to be normal in albino rats ranges from 70-140 $\mathrm{mg} / \mathrm{dl}$. Rats with glucose level above $200 \mathrm{mg} / \mathrm{dl}$ were considered as diabetic.

\subsection{Experimental Procedure}

Leaves of Brillantasia patula were obtained at Ovu-Inland,
Ethiope East Local Government Area, Delta State. They were carefully identified and authenticated at the Botany Department of the University of Benin, Benin city. The study consisted of six treatment groups, with five animals each, designated as Group 1 (healthy control), Group 2 (diabetic control) and Groups 3-6 (diabetic rats treated with 500, 1000, 1500 , and $2000 \mathrm{mg} / \mathrm{kg}$ bwt of aqueous extract of $B$. patula, respectively). Rats were given their apportioned doses orally, and daily, for a period of 14 days. After which the effects on serum glucose levels, liver and kidney functions, lipid peroxidation, free radical scavenger and hematological parameters were analyzed.

\subsection{Preparation of Serum}

Rats were sacrificed by cervical decapitation and blood was collected from the rats using syringe and EDTA container. This was allowed to clot and serum was stored at $20^{\circ} \mathrm{C}$ in the refrigerator until they are requested for use.

\subsection{Preparation of Tissue Homogenate}

$0.5 \mathrm{~g}$ of kidney, liver and heart was separately homogenized in $4.5 \mathrm{ml}$ of normal saline and centrifuged for $10 \mathrm{~min}$ at $4000 \mathrm{~g}$. The supernatants got were then stored at $4^{\circ} \mathrm{C}$ until needed for use.

\subsection{Biochemical Assays}

Total cholesterol, triglyceride, reduced glutathione and lipid peroxidation (malondialdehyde level) were assayed according to the method explained by Allain et al. [13], Fossati and Prencipe [14], Nakamura et al [15], and Deniz et al [16], respectively. The serum was used for the assay of alanine aminotransferase (ALT), aspartate aminotransferase (AST) as well as determination of total protein, creatinine, urea, haemoglobin $(\mathrm{Hb})$ concentration, packed cell volume (PCV) and catalase activity were determined by the methods outlined by Reitman and Frankel [17], Lyne [18], Bartels et al. [18], Palton et al [19], Cheesbrough [20] and Aebi [21], respectively.

\subsection{Statistical Analysis}

Statistical analysis was done using one-way analysis of variance (ANOVA) and comparison of mean values was done by Dunnet's post hoc test, using GraphPad Prism 5.0 software. Values of $\mathrm{p}<0.05$ were taken significant. Results were expressed as mean $\pm \mathrm{SD}$.

\section{Results}

\subsection{Effect of B. patula Aqueous Extract on Blood Glucose Levels}

Blood sugar levels significantly increased $(p<0.05)$ in the diabetic rats without treatment (Group2) and significantly decreased $(p<0.05)$ upon administration of the different concentrations of the plant's aqueous extract when matched with the diabetic control (group 2) (Figure 1). 


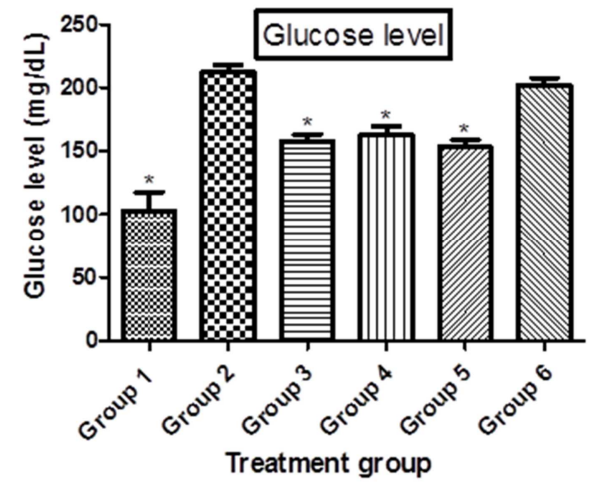

Figure 1. Random blood glucose level ( $\mathrm{mg} / \mathrm{dl}$ ) in diabetic rats treated with Brillantaisia patula aqueous extract. Group 1 (healthy control), Group 2 (diabetic control) and Groups 3-6 (diabetic rats treated with 500, 1000, 1500, and $2000 \mathrm{mg} / \mathrm{kg}$ bwt of aqueous extract of B. patula, respectively). *Significantly differs from the diabetic control (Group 2) at $P<0.05$ using Dunnet's post hoc test.

\subsection{Effect of B. patula Aqueous Extract on Kidney Function}

A significant reduction in serum creatinine levels was observed in group 3, 4 and 6 (lowest) while a significant increase $(\mathrm{p}<0.05)$ in group 5 (highest) was observed when compared with group 2 (Figure 2). The urea levels significantly decreased $(\mathrm{p}<0.05)$ in all groups treated with the aqueous extract when compared with the diabetic rats (Group 2) (Figure 2).
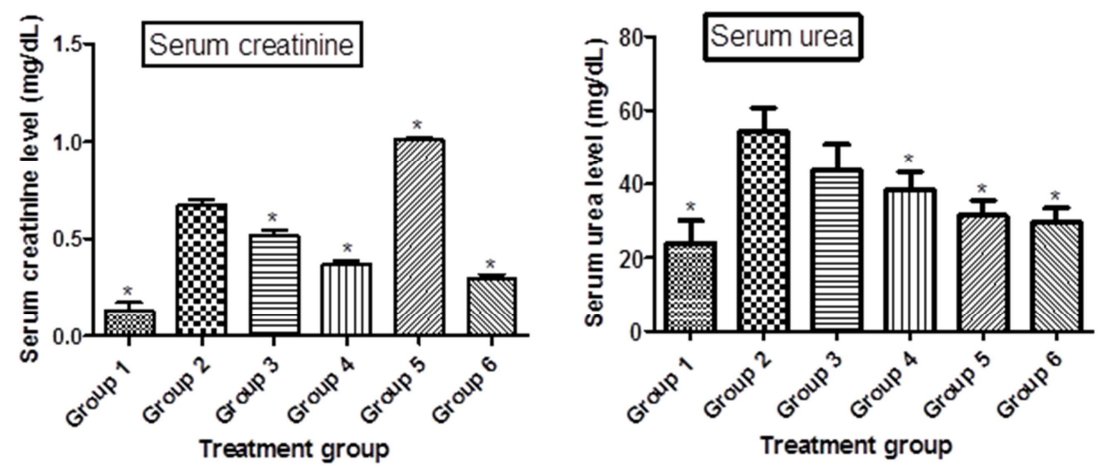

Figure 2. Effect of Brillantasia patula aqueous leaf extract on serum creatinine (mg/dl) and serum urea concentrations (mg/dl) of alloxan-induced diabetic rats. Group 1 (healthy control), Group 2 (diabetic control) and Groups 3-6 (diabetic rats treated with 500, 1000, 1500, and $2000 \mathrm{mg} / \mathrm{kg}$ bwt of aqueous extract of B. patula, respectively). *Significantly differs from the diabetic control (Group 2) at $P<0.05$ using Dunnet's post hoc test.

\subsection{Effect of B. patula Aqueous Extract on Lipid Profile and Soluble Protein}

There was a reduction in triglyceride levels in groups 3,4 and 5 when compared with the diabetic control (group 2); triglyceride level, however, increased $(\mathrm{p}<0.05)$ in group 6 rats (Figure 3). Whereas there was significant decrease $(\mathrm{p}<0.05)$ in cholesterol levels groups 3 and 5 animals,

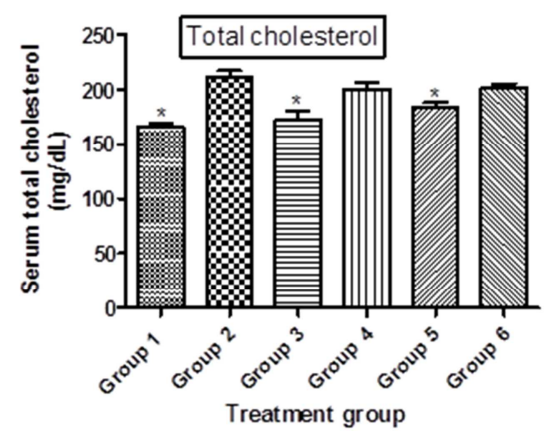

decrease in serum cholesterol levels observed in groups 4 and 6 animals was not significant when compared to the diabetic control $(p>0.05)$. The aqueous extract markedly reduced $(\mathrm{p}<0.05)$ serum total protein in all the treated groups when compared with the diabetic control. Similar trend was revealed by the result of serum concentrations of albumin and globulin (Figure 4).

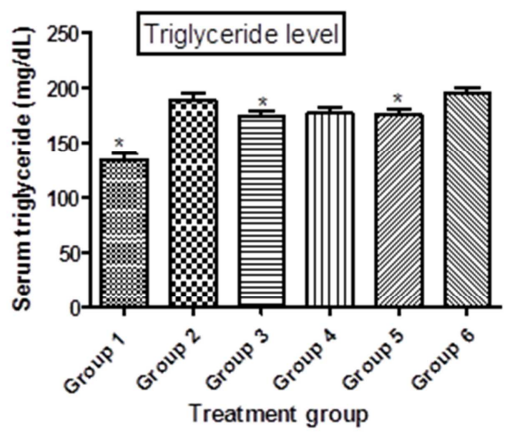

Figure 3. Effect of Brillantasia patula aqueous leaf extract on serum triglyceride and total cholesterol level (mg/dL) of alloxan-induced diabetic rats. Group 1 (healthy control), Group 2 (diabetic control) and Groups 3-6 (diabetic rats treated with 500, 1000, 1500, and $2000 \mathrm{mg} / \mathrm{kg}$ bwt of aqueous extract of B. patula, respectively). *Significantly differs from the diabetic control (Group 2) at $P<0.05$ using Dunnet's post hoc test. 

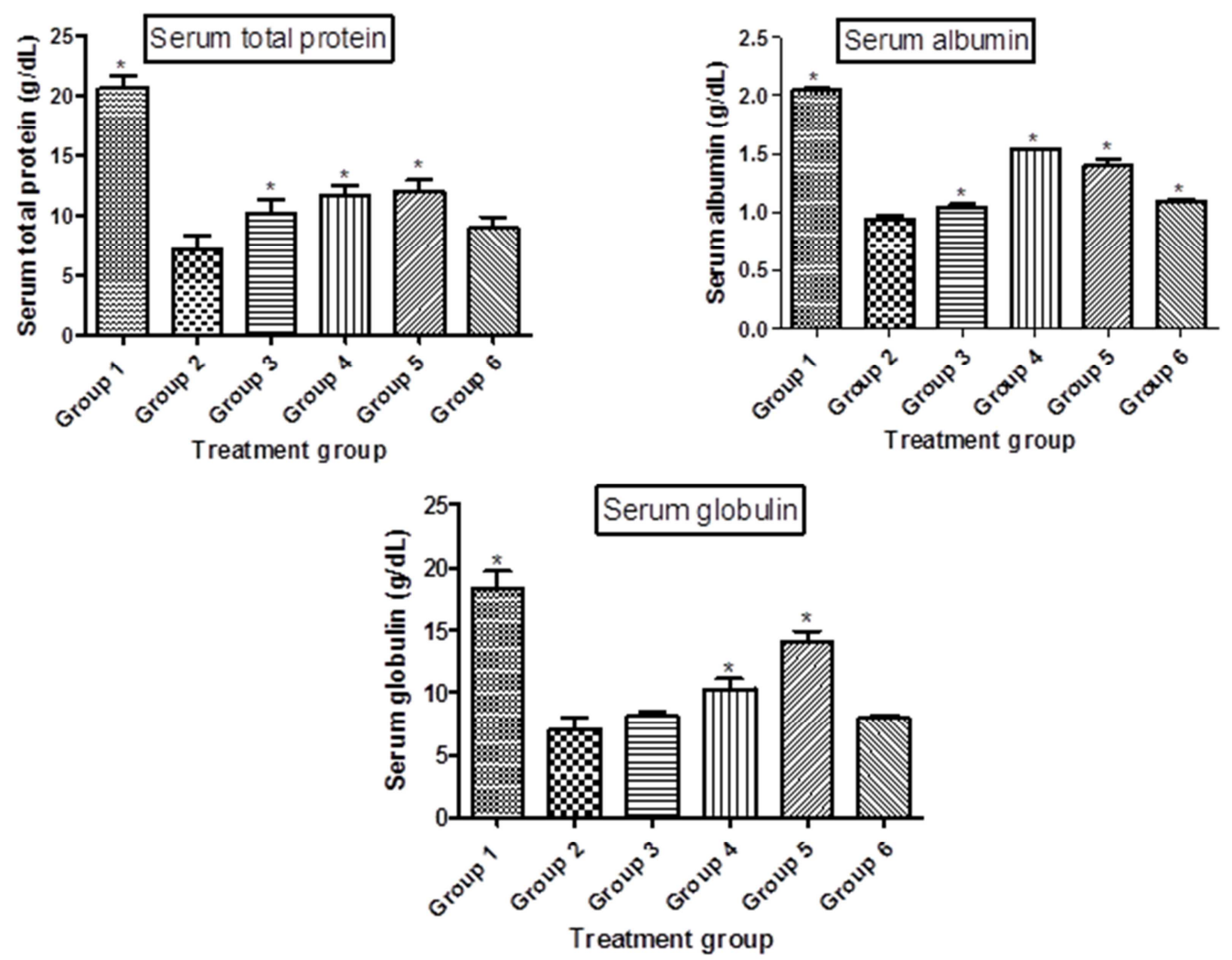

Figure 4. Effect of aqueous leaf extract of Brillantaisia patula on serum total protein, serum globulin and serum albumin levels in diabetic experimental rats. Group 1 (healthy control), Group 2 (diabetic control) and Groups 3-6 (diabetic rats treated with 500, 1000, 1500, and $2000 \mathrm{mg} / \mathrm{kg}$ bwt of aqueous extract of B. patula, respectively). *Significantly differs from the diabetic control (Group 2) at $P<0.05$ using Dunnet's post hoc test.

\subsection{Effect of B. patula Aqueous Extract on PCV and Hb}

The result of packed cell volume (PCV) shown in Figure 5 revealed that there was a significant increase in PCV in all the groups given the extract in comparison with group 2, the diabetic control $(\mathrm{p}<0.05)$. There was also an increase in haemoglobin concentration in diabetic rats treated with the plant extract when compared with group 2 , the diabetic control ( $\mathrm{p}>0.05)$.
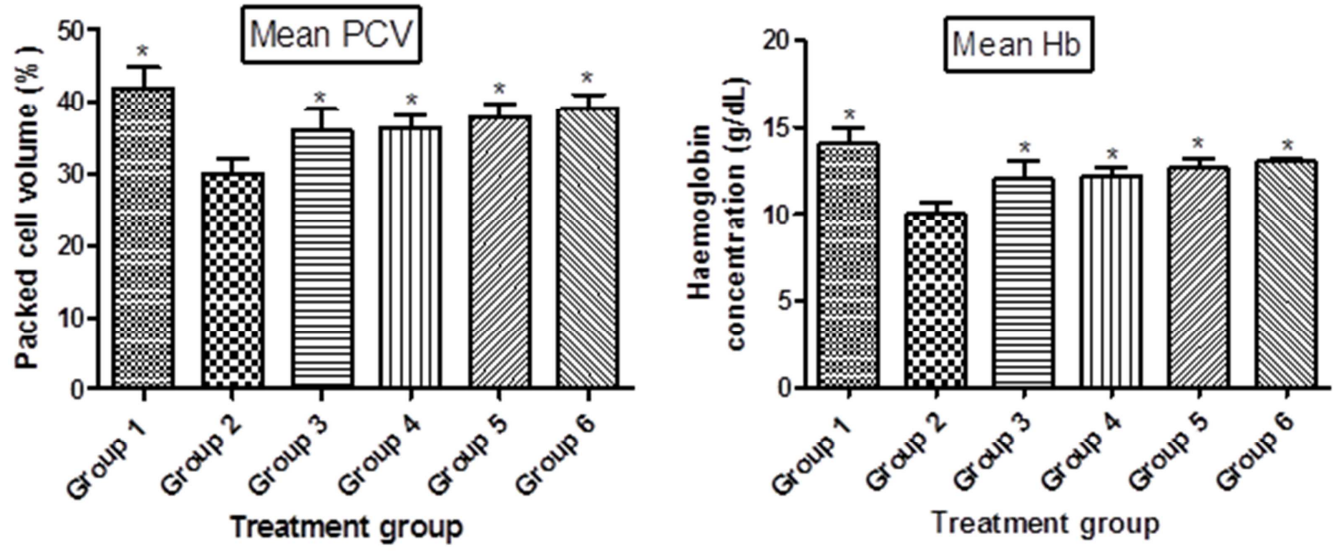

Figure 5. Packed cell volume (\%) and haemoglobin concentrations $(g / d L)$ in diabetic experimental rats treated with aqueous leaf extract of Brillantaisia patula. Group 1 (healthy control), Group 2 (diabetic control) and Groups 3-6 (diabetic rats treated with 500, 1000, 1500, and $2000 \mathrm{mg} / \mathrm{kg}$ bwt of aqueous extract of B. patula, respectively). *Significantly differs from the diabetic control (Group 2) at $P<0.05$ using Dunnet's post hoc test.

\subsection{Effect of B. patula Aqueous Extract on Liver Function}

The result of serum alanine aminotransferase (ALT) revealed that all treated groups showed significant reduction in the activity of ALT when juxtaposed with the positive diabetic control $\quad(\mathrm{p}<0.05) \quad($ Figure 6). Aspartate aminotransferase (AST) activity was also significantly reduced in groups 3, 4 and 6 while there was no significant difference in the activity of AST in group 5 when compared with the diabetic control $(\mathrm{p}>0.05)$. 

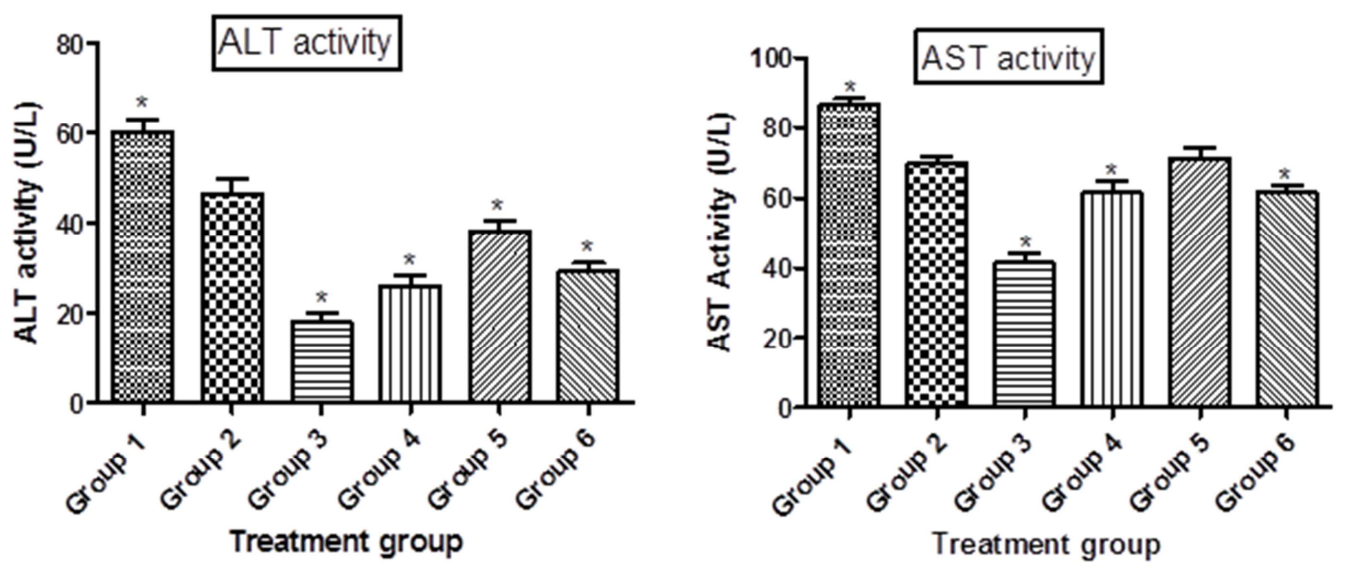

Figure 6. Effect of aqueous leaf extract of Brillantaisia patula on serum alanine transaminase (ALT) and aspartate transaminase (AST) in diabetic experimental rats. Group 1 (healthy control), Group 2 (diabetic control) and Groups 3-6 (diabetic rats treated with 500, 1000, 1500, and 2000 mg/kg bwt of aqueous extract of B. patula, respectively). *Significantly differs from the diabetic control (Group 2) at P<0.05 using Dunnet's post hoc test.

\subsection{Effect of B. patula Aqueous Extract on Antioxidant Status of Rats}

Increase in reduced glutathione levels (Figure 7) in the heart was observed in all the groups given the extract when matched with the diabetic positive control (group 2). A similar trend in glutathione level was also seen in that of the kidney and liver (Figure 7). The results of heart and kidney

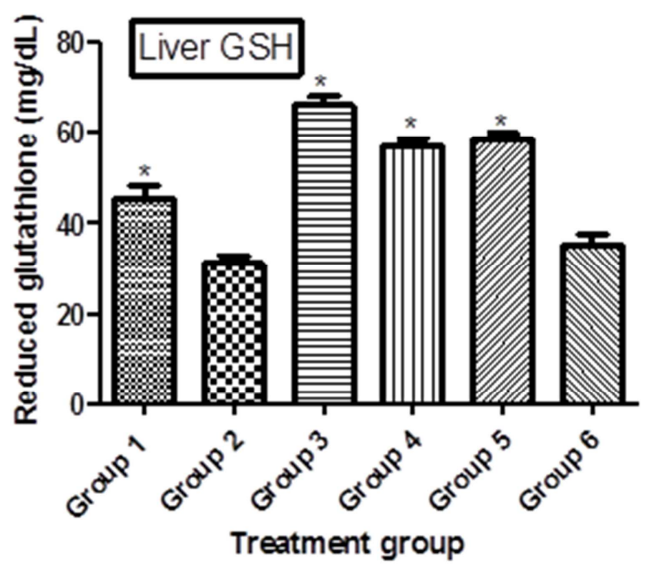

malondialdehyde (MDA) levels (Figure 8) revealed a marked reduction $(p<0.05)$ in the levels of heart MDA in all the groups given the extract when matched with both negative control (group 1) and positive control (group 2). Significant increase was observed in liver catalase activity in animals in groups 4, 5 and 6 when compared with the diabetic control, but not in groups 3 (Figure 9).

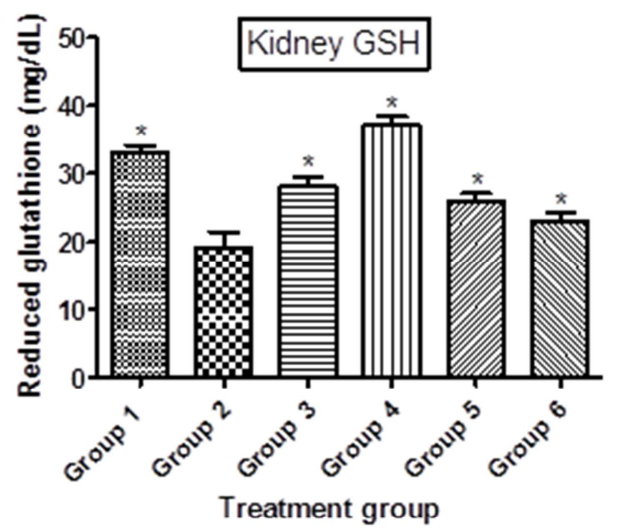

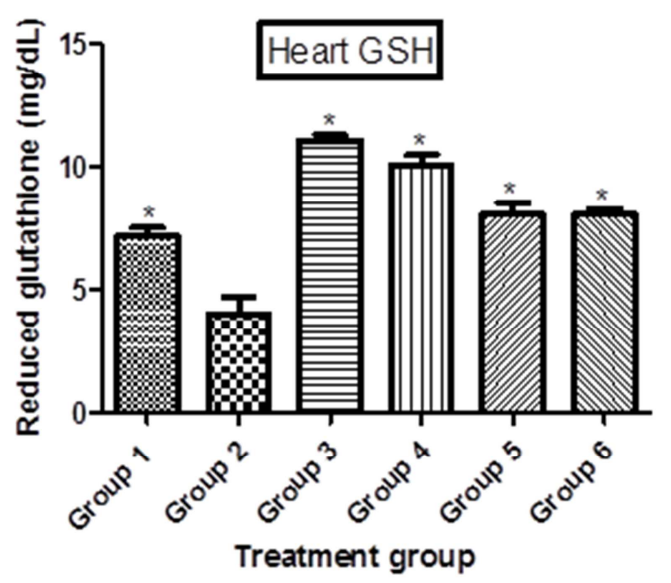

Figure 7. Levels of reduced glutathione $(\mathrm{mg} / \mathrm{dL})$ in liver, kidney and heart tissues of diabetic experimental rats treated with aqueous leaf extract of Brillantaisia patula. Group 1 (healthy control), Group 2 (diabetic control) and Groups 3-6 (diabetic rats treated with 500, 1000, 1500 , and 2000 mg/kg bwt of aqueous extract of B. patula, respectively). *Significantly differs from the diabetic control (Group 2) at $P<0.05$ using Dunnet's post hoc test. 

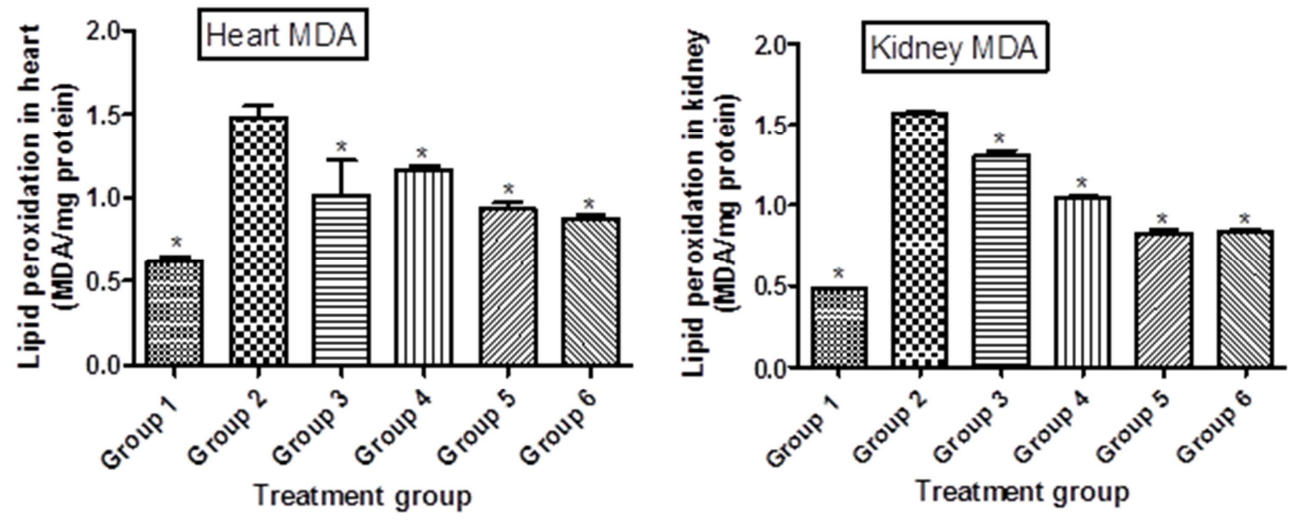

Figure 8. Protective effect of aqueous leaf extract of Brillantaisia patula against lipid peroxidation in diabetic experimental rats. MDA, Malondialdehyde. Group 1 (healthy control), Group 2 (diabetic control) and Groups 3-6 (diabetic rats treated with 500, 1000, 1500, and $2000 \mathrm{mg} / \mathrm{kg} \mathrm{bwt} \mathrm{of} \mathrm{aqueous} \mathrm{extract} \mathrm{of} \mathrm{B.}$ patula, respectively). *Significantly differs from the diabetic control (Group 2) at $P<0.05$ using Dunnet's post hoc test.

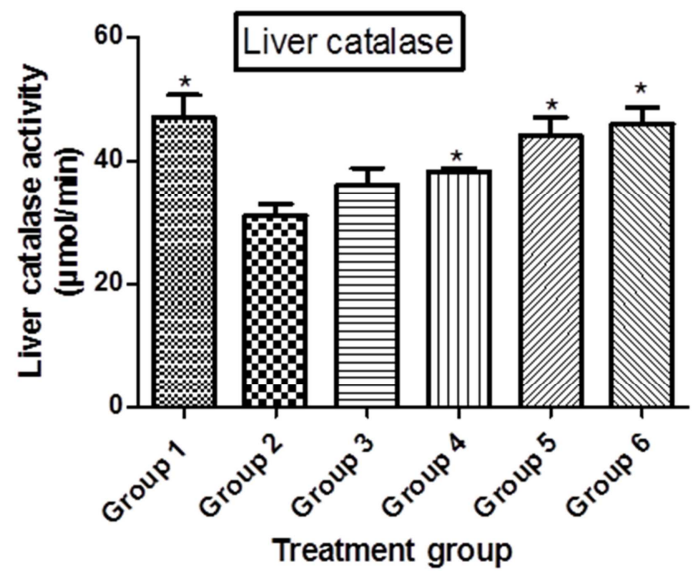

Figure 9. Catalase activity ( $\mu \mathrm{mol} / \mathrm{min}$ ) in liver of diabetic experimental rats treated with aqueous leaf extract of Brillantaisia patula. Group 1 (healthy control), Group 2 (diabetic control) and Groups 3-6 (diabetic rats treated with 500, 1000, 1500, and $2000 \mathrm{mg} / \mathrm{kg}$ bwt of aqueous extract of B. patula, respectively). *Significantly differs from the diabetic control (Group 2) at $P<0.05$ using Dunnet's post hoc test.

\section{Discussion}

Diabetes is a non-communicable disease that affects large population of the world and is characterized primarily by elevated blood glucose (hyperglyceamia) caused as a result of very little or deficiency of insulin, or when insulin receptors in the body do not respond appropriately to the presence of insulin $[22,23]$. Alloxan has been reported severally to cause destruction of the B cells that are involved in the synthesis of insulin in the pancreas leading to an elevation of glucose level in the blood [24]. In this study, a marked rise $(\mathrm{p}<0.05)$ in glucose level was noticed in rats injected only with alloxan but with no treatment (group 2) compared to the healthy control (group 1). The significant reduction observed in blood glucose levels in treated animal groups could be due to the restoration of the B cells of the pancreas involve in the secretion of insulin due to the presence of some antinutritional factors in the plant extract. The bioactive compounds in the extract may also lead to increased transport of blood glucose to the peripheral tissues $[22,25]$.
The increase in triglyceride observed in some treated groups may probably be as a result of insufficient insulin availability to trigger the uptake or utilization of glucose. Unusually high concentration of serum lipids caused by increase in the transportation of free fatty acids from the peripheral fat depots due to inhibition of the sensitive lipase by insulin has been reported [26, 27]. This prominent high lipid in the blood may therefore be taken as a result of the uninhibited actions of hormones involved in lipids catabolism on the fat depots caused probably by administration of the extract of the herb. The decrease observed in other group may be an indication of progressive metabolic control of Brillantaisia patula aqueous leaf extract on mechanisms involved in reduction or elimination of cholesterol from the body. This hypolipidemic properties by many medicinal plant species and plant products has been reported $[28,29]$.

The degradation of protein in the body ends up in urea production which is excreted from the body via kidney [30]. Creatinine is the final product of creatine kinase in the muscle cells. The amount of creatinine is a function of muscle mass and this is eliminated from the body through the kidney [30]. These two metabolites determine the healthy state of the kidney biochemically. Therefore an increase in these compounds is a reflection of kidney damage [30, 31]. The reduction in urea concentration observed in all the treated groups may probably be as a result of improvement of renal function by the administration of the aqueous extract of the leaf. A similar observation has been reported [32]. The decrease in creatinine concentration observed in some treated groups could be attributed to the effectiveness of the restoration of the impaired renal function by the presence of bioactive compounds extract [33, 34].

The effect of diabetes on protein metabolism has been previously reported [35]. The observed increase in serum total protein, albumin and globulin in diabetic animal groups treated with the aqueous extract of Brillantaisia patula (especially in groups 4 and 5 treated with 1000 and 1500 $\mathrm{mg} / \mathrm{kg}$ bwt, respectively) could be attributed to some bioactive compounds present in the aqueous leaf extract activating the uptake of amino acids and protein synthesis as well as inhibiting protein degradation [35]. 
The use of heamatological indices in establishing the harmful effects of xenobiotics has been reported [36]. Reduction of packed cell volume (aneamia) associated with diabetes mellitus has been attributed to increase in nonenzymatic glycosylation of RBC membrane proteins. As they undergo the oxidation, free radical species are produced such as lipid peroxides that can result to destruction of red blood cells (RBC) [37]. The increased packed cell volume (PCV) and haemoglobin $(\mathrm{Hb})$ noticed may be attributed to the phytochemical constituents of the extract improving the formation or release of erythropoietin in the stem cells of the bone marrow of the rats or lowering of lipid peroxidation by inhibition of the reaction by the plant extract [38].

Malondialdehyde (MDA) level, a biomarker of lipid peroxidation, is one of the major parameters used to ascertain the level of oxidant and antioxidant state of internal tissues in type 2 diabetics [39, 40]. The decreased concentration of malondialdehyde observed in the heart and kidney of the treated diabetic animal groups was an indication that lipid peroxidation was prevented. The decreased MDA levels in these tissues was also an indication of the inactivation of lipid peroxidation reactions and the decreased free radical generation caused by the components (phytochemicals) of extract of Brillantaisia patula.

Reduced glutathione (GSH) is an endogenous antioixidant biomolecule that fights against free radicals released resulting from oxidative stress. This implies that, a rise in GSH level can lead to reduction in lipid peroxidation [41]. Decreased glutathione levels found in the diabetic group without treatment is a sign of lipid peroxidation. The increase noticed upon treatment could be as a result of the activation of the synthesis of the bioactive compound by the presence of some phytochemicals available in the extract or the bioactive component of the extract are able to mop up the generated free radicals from the system. Catalase activity (CAT) has been reported to decrease in diabetic rats induced with streptozotocin [42]. The significant increase in catalase activity of the liver in the treated groups was an indication of the ameliorating effect of the extract increasing the synthesis of the enzymes.

Alanine- and aspartate transaminases are biomarker enzymes for liver function. Increase in the activity of these enzymes in the serum is an indication of liver impairment and this leads to the rupture of liver membrane resulting to leakage of these biomarker enzymes into the blood. Elevation in serum alanine aminotransferase (ALT) and aspartate aminotransferase (AST) in rats induced with alloxan has been published [43, 44]. The decrease in the activities of these enzymes in the treated groups revealed that the plant aqueous extract has protective effect on the integrity of the liver. This is in line with the work of Rajangam et al. [45].

\section{Conclusion}

The findings of the present study indicate that Brillantaisia patula aqueous leaf extract exhibits potential hypoglycemic effect, prevents lipid peroxidation, boosts haematological parameters, and could protect liver and renal damage associated with type 2 diabetes, especially when administered at a dose range of $500-1000 \mathrm{mg} / \mathrm{kgbwt}$. Future studies to identify the bioactive constituents are, however, encouraged.

\section{Acknowledgements}

We are grateful to African Research Laboratories (ARL), Otorho-Agbon, Delta State, Nigeria for granting access to her facilities as well as Mr Fredrick Omererione who helped us in sourcing for the plant from its ecological niche.

\section{References}

[1] Adoum, O. A., Micheal, B. O., Mohammad, I. S. Phytochemicals and hypoglycaemic effect of methanol stembark extract of Ficus sycomorus Linn (Moraceae) on alloxan induced diabetic Wistar albino rats. Afri J Biotechnol 2012; 11(17): 4095-4097.

[2] Onyesom, I., Ogbodu, E. D., Osioma, E., Avwioroko, O. J. Injectable progestin contraceptive could increase the risk of insulin resistance syndrome in humans. Inter $\mathrm{J}$ Biochem Photon 2013; 108: 225-230.

[3] Sassy-Prigent, C., Heudes, D., Jouquey, S., Auberval, D., Beliar, M., Michel, O., Hamon, G., Schwartz, C., Valente, A., Sprague, E. (1995) A modern view of atherogenesis. Am. J. Cardiol. 71:9-4.

[4] Arise, R., Malomo, S., Adebayo, J., Igunnu, A. Effects of aqueous extract of Eucalyptus globules on lipid peroxidation and selected enzymes of rat's liver. J. Med. Plant Res 2009; 077-081.

[5] Anigboro, A. A, Onakurhefe, P., Tonukari, N. J., Avwioroko, O. J., Egbeme E. Quantitative determination of some phytochemicals (phenol, flavonoid, saponin and alkaloid) in twenty-two Nigerian medicinal plants. Nig J Sci Environ 2014; 13(1):86-93.

[6] Marles, J., Farnsworth, N. Antidiabetic plants and their active constituents. Phytomedicine 1995; 2(2):123-185.

[7] Orororo, O. C., Tonukari, N. J., Avwioroko, O. J., Ezedom, T. Effect of supplementation of animal feed with dried cassava (Manihot esculenta) peels, and stems of Vernonia amygdalina and Pennisetum purpereum on some biochemical parameters in pigs. NISEB J 2014; 14(4): 177-183.

[8] Anigboro, A. A, Avwioroko, O. J., Ohwokevwo, O. A., Nzor, J. N. Phytochemical constituents, antidiabetic and ameliorative effects of Polyalthia longifiola leaf extract against alterations in hepatic and renal functions in alloxaninduced diabetic rats. J. Appl. Sci. Environ. Manag. 2018; In Press (Accepted).

[9] Gupta, R. C., Chang, D., Nammi, S., Bensoussan, A., Bilinski, K., Roufogalis, B. D. Interactions between antidiabetic drugs and herbs: an overview of mechanisms of action and clinical implications. Diabetol. Metabol. syndrome 2017; 9(1):59.

[10] Chudasama, R. G., Dhanani, N. J., Amrutiya, R. M., Chandni, R., Jayanthi, G., Karthikeyan, K. Screening of selected plants from semi-arid region for its phytochemical constituents and antimicrobial activity. J. Pharmacog. Phytochem. 2018; 7(2): 2983-2988. 
[11] Yamagishi, S. I., Matsui, T., Ishibashi, Y., Isami, F., Abe, Y., Sakaguchi, T., Higashimoto, Y. Phytochemicals against advanced glycation end products (AGEs) and the receptor system. Curr. Pharmaceut. Design 2017; 23(8): 1135-1141.

[12] Makambila-Koubemba, M., Mbatchi, B., Ardid, D., Gelot, A., Henrion, C. et al. Pharmacological studies of ten medicinal plants used for analgesic purposes in congo Brazzaville. Int. J. Pharmacol 2011; 7:608-615.

[13] Allain, C. C., Poon, L. S. Cicely, S. G. Enzymatic Determination of Total Serum Cholesterol. Clin. Chem 1974; 20: $470-475$

[14] Fossati, P. C., L. Prencipe. Triglycerides determination after enzymatic hydorolysis, Clin. Chem 1982; 28: 2077.

[15] Nakamura, W., Hojoda, S., Hayashi, K. Purification and Properties of Rat Liver Glutathione Peroxidase. Biochimica et Biophysica Acta 1974; 358: 251-261.

[16] Deniz S., Arzu S., Figen I., Gulden C. Lipid peroxidation and antioxidant status in experimental animals. Effects of aging and hypercholesterolemic diet. Clin. Chem. Acta 1997; 265: $77-82$.

[17] Reitman S., Frankel, S. Colorimetric Method for Determination of Serum GOT and GPT. Am J Clin Pathol 1957; 28-56.

[18] Bartels H., Boehmer M. Microdetermination of creatinine. Clin. Chim. Acta 1971: 32:81-85.

[19] Lyne, E. Spectrophotometric and Turbidometric Methods for Measuring Proteins. Methods in Enzymol 1957; 10: 447-455.

[20] Palton C. J., Crouch S. R. Spectrophotometric and kinetics investigation of the Berthelot reaction for the determination of ammonia. Anal Chem 1977; 49:464-469.

[21] Cheesbrough, M. District Laboratory Practice in Tropical Countries, part 2. Cambridge University Press 2004; pp 249258.

[22] Aebi H. Catalase in vitro. In: Methods in Enzymology. Academic Press, New York, 1984; pp. 479-500.

[23] Hjort, R., Alfredsson, L., Andersson, T., Carlsson, P. O., Grill, V., Groop, L., et al. Family history of type 1 and type 2 diabetes and risk of latent autoimmune diabetes in adults (LADA). Diabetes and metabolism 2017; 43(6): 536-542. https://doi.org/10.1016/j.diabet.2017.05.010

[24] Swasey, K. K., Orchard, T. J., Costacou, T. Trends in cardiovascular risk factor management in type 1 diabetes by sex. $J$ Diabetes Complic 2018; 32(4): 411-417. https://doi.org/10.1016/j.jdiacomp.2018.01.003

[25] Akindele OA, Babatunde AI, Chinedu FM, Samuel OA, Oluwasola CA, Oluseyi AA. Rat model of food induced nonobese-type 2 diabetes mellitus; comparative pathophysology and histopathology. Inter J Physiol Pathophysiol Pharmacol 2012; 4(1): 51-58.

[26] Arha, D., Ramakrishna, E., Gupta, A. P., Rai, A. K., Sharma, A., Ahmad, I., Riyazuddin, M., Gayen, J. R., Maurya, R. and Tamrakar, A. K. Isoalantolactone derivative promotes glucose utilization in skeletal muscle cells and increases energy expenditure in $\mathrm{db} / \mathrm{db}$ mice via activating AMPK-dependent signaling. Mol. Cellular Endocrinol. 2018; 460:134-151.

[27] Kurek, K., Garbowska, M., Ziembicka, D. M., Łukaszuk, B.,
Rogowski, J., Chabowski, A., Górski, J. and ŻendzianPiotrowska, M. Myriocin treatment affects lipid metabolism in skeletal muscles of rats with streptozotocin-induced type 1 diabetes. Adv. Medical Sci., 2017; 62(1):65-73.

[28] Al-Sharmaony, L., Al-Khazraji, S., Twaji, H. Hypoglycemic effect of a valuable extract on some blood glucose parameters in diabetic animals. J. Ethnopharmacol 2004; 43:167-171.

[29] Aganbi, E., Avwioroko, O. J., Enabulele, E. R., Osagu, J. O., Uwandu, C. K., Ike, A., et al. Amelioration of lead-induced toxicity in blood, liver and kidney tissues of male wistar rats by fermented Ofada rice. Turkish J Agric - Food Sc Technol 2015; 3(9): 754-759.

[30] Akah JA, Lemji JA, Salawa OA, Okoye TC, Offiah NV (2009). Effects of Vernonia amygdalina on Biochemical and Haematological Parameters in Diabetic Rats. Asian J Medicinal Sci 2009; 1(3): 108-113.

[31] Parr, S. K., Matheny, M. E., Abdel-Kader, K., Greevy Jr, R. A., Bian, A., Fly, J., et al. Acute kidney injury is a risk factor for subsequent proteinuria. Kidney Inter 2017; 93(2): 460-469.

[32] Bhargavi, G., Josthna, P., Naidu, CV. Changes in serum biochemical parameters and lipid profile in normal and STZ induced diabetic rats with the administration of ethanolic extract of Polpalthia cerasiodes stem bark. Intl. Res J. Pharm.2015; 6(2): 153-156.

[33] Daisy, P., Nirmala, A., Rajathi, M. Hypoglycemic and other related effects of Elephantopus seaber extracts on alloxaninduced diabetic rats. J. Biol. Sci. 2007; 7:433-437.

[34] Enogieru A. B., Momodu O. I., Omoruyi S. I., Om'iniabohs F. A. E. Changes in Biochemical Markers of Kidney Function and Antioxidant Status of Diabetic Rats treated with Aqueous Leaf Extracts of Ficus exasperata (Vahl). Afr J Biomed Res 2015; 18: 61- 67 .

[35] Pathak, A., Dhawan, D. Effects of lithium on the levels of blood urea and creatinine in diabetic rats. Med Sci Res 1998; 26:855-859

[36] Ren, T., Zhu, Y., Xia, X., Ding, Y., Guo, J. and Kan, J.. Zanthoxylum alkylamides ameliorate protein metabolism disorder in STZ-induced diabetic rats. J Mol Endocrinol, 2017; 58(3): 113-125.

[37] Edet, A. E., Patrick, E. B., Olarunfemi, E. A. Hematological Parameters of Alloxan-Induced Diabetic Rats Treated With Ethanol Extracts and Fractions of Naudea lafiloia Leaf. European Scientific J 2013; 9(27)203-10.

[38] Kothari, R., Bokariya, P. A Comparative Study of Haematological Parameters in Type 1 Diabetes Mellitus Patients \& Healthy Young Adolescents. Int J Biol Med Res 2012; 3(4): 2429-32.

[39] Ashafa, A. O. T., Yakubu, M. T., Grierson, D. S., Afolayan, A. J. Toxicological Evaluation of the Aqueous Extract of Felicia muricata Thiemb Leaves in Wistar rats. Afri J Biolechnol 2009; 6(4): 949 - 954.

[40] Tangvarasittichai, S. Serum levels of malondialdehyde in type 2 diabetes mellitus Thai subjects. Siriraj Medical J 2017; 61(1): 20-23.

[41] Tsikas, D. Assessment of lipid peroxidation by measuring malondialdehyde (MDA) and relatives in biological samples: Analytical and biological challenges. Analytical biochemistry, 2017; 524:13-30. https://doi.org/10.1016/j.ab.2016.10.021 
[42] Yin, L., Mano, J. I., Tanaka, K., Wang, S., Zhang, M., Deng, X., Zhang, S. High level of reduced glutathione contributes to detoxification of lipid peroxide-derived reactive carbonyl species in transgenic Arabidopsis overexpressing glutathione reductase under aluminum stress. Physiologia plantarum, 2017; 161(2): 211-223.

[43] Cho S. Y., Park J. Y., Park E. M., Choi M. S., Lee M. K., Jeon S. M., et al. Alternation of hepatic antioxidant enzyme activities and lipid profile in streptozotocin-induced diabetic rats by supplementation of dandelion water extract. Clin Chim Acta 2002; 317: 109-117.
[44] Whitehead MW, Hawkes ND, Hainsworth I, Kingham, JG. A prospective study of the causes of notably raised aspartate aminotransferase of liver origin. Gut. 1999; 45:129-133.

[45] Harris E. Elevated liver function tests in type 2 diabetes. Clin Diabetes 2005; 23:115-119.

[46] Rajangam, U., Sampath, K., Thankaraj, S. M., Manoharan, R., Vasudevan, R. A., Sei, C. K., Andy, G., W. C. Hypoglycemic and Hypolipidaemic Effects of Withania somnifera Root and Leaf Extracts on Alloxan-Induced Diabetic Rats. Int. J. Mol. Sci 2009; 10: 2367-2382. 